\title{
Scottish Soldier-heroes and Patriotic War Heroines: the Gendered Politics of World War I Commemoration
}

\author{
Nataliya Danilova and Emma Dolan \\ University of Aberdeen
}

\begin{abstract}
This paper explores the (re)production of embodied gendered and racialised identities as part of commemorations devised by the Scottish government to mark the Centenary of WWI, 201418. In particular, we demonstrate how the Centenary has re-established Scotland's key contribution to British military power instead of providing a platform for a broader discussion of British wars and Scotland's role therein. Our analysis posits that this reframing was achieved through the (re)production of a gendered polarisation between white 'dead' soldier-heroes, 'local lads' and bearers of a 'proud Scottish military tradition'; and women as embodiments of patriotic motherhood. We further explore the deployment of specific discursive and performative means to transform Dr Elsie Inglis, the only woman whose contribution was singled out by WW100 Scotland, into a patriotic war heroine. This was achieved by the militarisation of her work; the obscuring of identity, class- and race-based hierarchies within women's war-work; and, finally, through the subversion of feminist ideas and practices in Inglis' work for the Scottish Women's Hospitals. Lastly, we reflect on the gendered legacy of the Centenary, emphasising the necessity for critical engagement with Britain's wars and Scotland's role therein.
\end{abstract}

Key words: gender, commemoration, performance, militarisation, Britain 


\section{Introduction}

The Centenary of WWI has become a focal point for the transnational politics of war commemoration with the governments of the UK, the Commonwealth (primarily Australia, Canada and New Zealand), France, Germany, Belgium, the Netherlands and Russia busying themselves with setting up commemorative panels (e.g. Fathi 2015; Arnold de-Simine 2016; Wellings 2016). In each country, the dynamic of commemorations took a different route. Notably, a 'memory orgy' was observed in the Anglo-Saxon countries, a phenomenon which observers have explained by: the common traditions of 'poppy-wearing and remembrance of the dead each November' (Moore 2014, 428); fragmentations of national identity projects caused by concerns over immigration and anxieties resulting from the prolonged engagement of these countries in conflicts under the banner of the Global War on Terror (Pennell 2014; Beaumont 2015; Jeffery 2015). This paper posits that the Centenary has presented not only an 'once in a lifetime opportunity' to commemorate WWI (Sheffield 2014), but has become an opportunity to reframe anxieties existing within Western polities through the (re)production of particular 'embodied gendered, sexualised, and racial identities' of those whose sacrifice is seen as worthy of remembrance (Basham 2013, 47). Drawing on analysis of parliamentary debates, commemorative publications, stenogrammes of official meetings, participant fieldwork ethnographies and materials from interviews with policy-makers, ${ }^{1}$ we interrogate how particular gendered, sexualised and racialised hierarchies have been (re)produced through Scottish commemorations of WWI.

Our approach to war commemoration builds on interdisciplinary literature from International Relations (IR), the sub-discipline of Critical Military Studies (CMS), memory politics and literature relating to Scottish history and politics. Specifically, we conceptualise war commemoration as a 'primarily political project' in which 'the state and its institutions mediate and order formal and informal collective histories and memories' (Mycock 2014, 154). We explore which political practices have been deployed by the Scottish government to identify both the focal points of the Centenary and specific groups the remembrance of whom has been made (in)visible through this process. We are particularly concerned with answering two questions: who has ownership over the Centenary?; and what are the political implications of how the Centenary is performed in public spaces? To answer these questions, we draw on feminist scholarship relating to the everyday politics of collective mourning (e.g. Butler 2003; 
Edkins 2003). This literature explores collective mourning and commemoration as key discursive and performative spaces for 'the identification with suffering itself' (Butler 2003, 30), where 'subtle movements, bodies and emotions' enact a specific - gendered - vision of the political community (Ähall 2016). Through this paper we work towards the (re)framing of public commemoration as a complex process mediated by particular visions of the political as well as visions of commemorative masculinities and femininities. This approach draws attention to gendered discursive and performative means, which deliminate power relations in making commemorative choices, organise public spaces for commemoration thereby (in)visibilising experiences of those commemorated.

To study the gendered logics of the political in commemoration, we focus on the marking of the Centenary in Scotland. Despite growing literature relating to the Centenary within British politics, there has been a lack of scholarly attention given to Scottish commemorations (e.g. Pennell 2014; Jeffery 2015). This is surprising considering the unique political context, including but not limited to devolution (from 1999, onwards), the 2014 Independence Referendum and the 2016 Brexit vote. In 2012-14, many observers of the strained relationship between Scotland and the rest of the UK were sceptical of David Cameron's plan to enact 'a truly national commemoration' considering it naive because it failed to acknowledge the layering and fragmenting of war commemoration (Mycock 2014).

At the outset the UK government reinstated the "British understandings of the war..., marginalising the divergent experiences of other nations within and outside the UK (Pennell 2014, 97). Hence, Mycock (2014) predicted that the Centenary would '(re)ignite a diverse range of post-colonial responses' across the UK $(2014,161)$. At a special service at Glasgow Cathedral on 4 August 2014, which concluded 11 days of the Commonwealth Games and marked the opening of the Centenary, Alex Salmond and David Cameron articulated strikingly different visions of WWI. Salmond substantially exaggerated Scottish losses, saying that 'the war claimed the lives of 145,000 Scots', whilst Cameron stressed the loss of all British lives (circa a million) (BBC 2014).

Acknowledging this context, we draw attention to an ambivalent positionality of Scotland in the British military project. This ambivalence results from a continious support for the Scottish martial tradition and Scottish soldiers. As Cameron points out, the 'coincidence' of the 2014 Referendum and the Centenary worked towards reinforcing the idea of Scotland's essential 
contribution to 'the defence of the UK in its hours of need' $(2018,67)$. In 2013-14, this discourse overlapped with the representation of Scotland as a country with a 'hard-won reputation for being Bravehearts in the battle' (Salmond 2014), which was based on the selective reuse of Scottish pre-Union war-stories and heroes (e.g. William Wallace and Robert the Bruce) along with selective references to historical 'martial race' discourse of Highland warriors who distinguished themselves through their service in the Scottish regiments at the time of the British Empire (e.g. Street 2004). For years, this white male-centric 'warrior dreamscape' has also been fostered by government-sponsored tourist advertising campaigns (VisitScotland), large-scale cultural events (Royal Edinburgh Military Tattoo), and productions, such as Highlander (1986), Braveheart (1995), Outlander (2014), and Outlaw King (2018) (e.g. Hesse 2014; see also Devine 2012; Allan 2015; McCrone 2017).

Importantly, we argue that neither opposition to nuclear weapons or the Iraq War has challenged the popular discourse of Scotland's military prowess (Ritchi 2016). On the contrary, although in 2003, the position of Scottish political elites and the wider electorate diverged from the Westminster position towards British military engagement in Iraq, contrasting 'British warriors' with 'anti-war-minded Scots' (Elcheroth and Reicher 2017, 215-6), elites in Scotland were united in support of the 'virtuous troops' and "'the poor bloody infantry", who are as ever traduced by their leaders in war' (ibid, 238). Thus, prior to the Centenary, Scottish elites advocated support for Scottish infantry soldiers, whilst simultaneously both transferring the responsibility for Britain's wars to the UK government and marginalising Scotland's own role in past and present conflicts.

We first analyse official discourses and practices focusing on how the Scottish Commemorations Panel has prioritised experiences of white local 'dead' heroes and reduced women's roles to performances of essentialised patriotic womanhood. Following this, we explore how patriotic womanhood was enacted in the commemoration of Dr Elsie Inglis, the only woman whose contribution to WWI was singled out by the Panel, before looking at the opportunities for critical engagement with Britain's wars and Scotland's role therein.

\section{Scottish Commemorations Panel: From inclusivity towards 'soldier-dead'}

In Britain, 'the centenary commemoration of the First World War has been driven by a combination of central government direction (and funding) with a multitude of local and 
community initiatives' (Jeffery 2015, 562). The majority of local initiatives were funded through the Heritage Lottery Fund, which by 18 March 2018 awarded $£ 94.2$ million to 2000 projects across the UK, including to projects carried out by communities across Scotland (Brookfield 2018, 119-21). However, as the UK government prioritised the overarching British narrative and allocated the main bulk of this funding to national museums (i.e. London's IWM), national cultural institutions (i.e. the BBC), and the organisation of battlefield tours for schools based in England, the Centenary emerged as both an opportunity and somewhat a necessity for governments of devolved nations (Scotland, Wales and Northern Ireland) to devise their own commemorative projects.

In Scotland, this process culminated in the creation of the government-funded Scottish Commemorations Panel (dubbed 'Scotland WW100'). Panel members were appointed by the Scottish Government with specific decisions delegated to the Cabinet Secretary for Culture and External Affairs, Fiona Hyslop (Scottish Parliament 2013). The panel itself was placed within 'Culture, Tourism and Major Events Directorate', reflecting the convergence of commemoration with cultural 'memory' tourism alongside Scotland's self-branding as a country with rich military heritage (Sturken 2007).

Like British and Australian panels, the Scottish 12-member panel can be described as being composed of 'the good and the great' (Jeffery 2015, 563; Beamont 2015). Commemorative authority was delegated to those with both military expertise and associations with Scotland, including: Professor and former Army chaplain Norman Drummond as panel chair; historians of WWI and Scottish heritage; a representative of BBC Scotland; representatives of Scottish education and veterans' organisations (e.g. Royal British Legion Scotland); and other interested parties (e.g. Scotland-based entrepreneurs) (WW100 2018). This delegation of commemorative authority to a closed group of experts highlighted three aspects of the Scottish setting: a tendency to rely on expert-bureaucratic procedures, male-dominated expertise and military ownership of the Centenary.

First, the creation of the panel reflected a tendency within the Scottish policy process to overrely on 'expert-bureaucratic' procedures, contrary to the popular belief that Scotland has 'a more inclusive and participatory approach to policy making than Westminster' (Johnson and Fife 2016, 174). This expertise framing reflected an attempt by the Scottish Government and SNP 'not to take decision in its own right' by abstaining from participation in the panel's 
decisions, and through this attempting to dissociate the Centenary from the divisive legacy of the 2014 Independence Referendum (Interviewee R, a SNP MSP, 12 Jan 2018). As transpired from the interview with one panel member, the selection of members was administrated through closed government channels, and was largely based on inviting those with expertise in Scottish war history, experience of military service and without associations with political parties (Interviewee T, 27 Nov 2017). This step demonstrated the unwillingness of Scottish elites to open-up the Centenary to public deliberation using a set of discouraging practices, such as 'non-invitation' of political party representatives to the panel; introducting the panel's decisions to the Scottish Parliament as a matter of 'what has been decided' rather than a matter of 'what needs to be discussed', including the sensitive issue of commemorative budgets; and limited opportunities for the wider public to voice their visions of what, who and how should be commemorated. Consequently, according to interviews with panel representatives, the meetings were 'apolitical', 'tension-free', and 'above politics'; with those attending the meetings largely in agreement (extracted from interviews with panel members E, 2 Aug 2017; L, 2 Aug 2017; and T, 27 Nov 2017). This policy-setting prioritised experts 'sensitively handling' the Centenary through 'balancing tone of remembrance and celebration' and 'managing diverse messages and moods' (Scottish Government 2013), thereby dissociating the Centenary from nationalistic readings of WWI, voiced prior to the 2014 Referendum.

Second, 'despite the relatively high number of female politicians in Scotland' and women leaders in the three national political parties, the 'face' of Scottish commemorative expertise has replicated the 'face' of Scottish independence debates with both 'faces' being 'male, pale and stale' (Kenny 2014, 324). These three characteristics introduce white male privilege and respect for age as key components of Scottish commemorative expertise. Moreover, contrary to the perception of 'a more intimate politics' exercised by Nicola Sturgeon (Higgins and McKay 2016), our analysis suggests that Sturgeon's role was reduced to symbolic participation in commemorative events. Based on interviews, Sturgeon was 'punctilious' in 'playing commemoration as a story of joint commemoration [with the rest of the UK], not of a national idea-agenda' as Salmond claimed prior to the 2014 Referendum (Interviewee T, 27 Nov 2017). Therefore, neither the expert-led structure of the panel nor the position of Scottish leadership from September 2014 onwards favoured the narrative of 'internal colonialization' predicted by Mycock (2014). Instead the panel worked towards the synchronisation of white maledominated commemorative discourses promoted by both the Scottish and UK governments. 
Finally, the panel introduced those with military connections as the true 'owners' of the Centenary. Towards this goal, the panel closely cooperated with the Royal British Legion Scotland, the organisation which officially describes itself as 'the national guardian of remembrance' (RBLS 2018). Reflecting this collaboration, Alex Salmond announced the creation of the panel at the Royal British Legion Scotland conference in Perth, the main recruiting ground for the famous Black Watch regiment/battalion (BBC 2013). Between 2014 and 2018, members of this organisation have played a key role in advising the panel, organising events, and accompanying school children on government-funded battlefield tours. This convergence between government and veterans' structures transformed the Centenary into an opportunity for honouring Scotland's 'long and distinguished military history' (Scottish Parliament 2013), placing Scotland within the British military project rather than in opposition to it as Mycock suggested (2014). This emphasis on Scottish martial tradition worked to obscure a wide range of experiences felt and lived by Scots during WWI while also marginalising discussions of Scotland's contribution to British colonial wars (Mycock 2012, 63), along with debates on what WWI and the following conflicts (e.g. the Global War on Terror) entail for multiracial communities currently residing in Scotland.

The resultant setting has reinstated the white male soldier as the main referent of public grief and compassion, a trend which is currently observed in other Western democracies (Butler 2009; Millar 2017). This emphasis emerged despite the explicit commitment of the Scottish government to inclusivity and diversity, and Fiona Hyslop's support for the Scottish commemorations to be able to reflect experiences of 'ordinary people and officers' (MSP John Mason, Glasgow, SNP), soldiers from the Commonwealth and the Indian subcontinent (MSP Hanzala Malik, Glasgow, Labour), and the 'men and women of our armed forces who lost their lives in that war and others since' (MSP Richard Lyle, Central Scotland, SNP) (Scottish Parliament 2013). Moreover, the Scottish 'soldier-dead' narrative was fostered through the selection of the eight events in which 'Scotland took a particularly bad hit' (Interviewee R, a SNP MSP, 12 Jan 2018), including the outbreak of war, the day of peace treaty, four major battles (Gallipoli, Battle of Loos, Battle of Jutland, Battle of Arras) and two disasters, which led to the death and injury of Scottish soldiers arriving to or leaving the front (i.e. train crash at Quintinshill and loss of HMY Iolaire a mile from Stornoway). Although the panel attempted to move beyond battlefield deaths prioritised by the UK Government, this shift did not destabilise the white 'soldier-dead' narrative. On the contrary, it placed soldiering and, may we add, dying for the country, at the centre of the Centenary. 
Our analysis posits that the policy of 'marrying of education with remembrance' emerged as a key dimension of the Centenary, replicating the position of the UK government (Pennell 2018, 93). This policy put particular emphasis on local 'soldier-dead' fostered through distribution of the main bulk of government funding to the refurbishment of local war memorials $(£ 1 \mathrm{mln})$ and battlefield tours for over 20,000 of Scottish children to France in addition to 72 students from Secondary 3 Level travelling to commemorate the Battle of Arras (Scottish Government 2013). In most cases, the focus of this war-centred education was on experiences of 'local lads' and, only in rare cases, locally-born nurses. To achieve this, children have been invited to visit memorials, undertake battlefield tours, create posters, write war poems and produce art works dedicated to locally-born soldiers.

Three problematic implications of educational remembrance are worth discussing. First, as Pennell (2018) demonstrates through the analysis of battlefield tours for children from English schools, war memorials and military cemeteries have limited capacity to engage children in the study of the complex historical circumstances which led to WWI. These sites do not encourage children to 'truly understand' the experiences of 'ordinary' soldiers due to the limited contextualisation available, and instead such places tend to overwhelm children with 'the sheer emotional impact', encouraging sympathy with losses, 'loyalty to the dead' along with support and 'understanding' of those who served and continue to serve in the British Armed Forces. In our study, the panel members emphasised the emotional impact of the trip to the Battle of Arras, when 'kids just got it' and 'truly learnt about sacrifice and loyalty', but when prompted on what children learnt about this battle as part of WWI history, clarified that the primary goal of these tours was 'to teach children to understand war in a small way' through the stories about soldiering and comradership (Interviewee E and L, 2 Aug 2017). This explanation resonates with Pennell's argument that the battlefield tours tend to focus on affective responses to war expressed through compassion with locally-born soldiers instead of providing a route to complex understandings of this conflict or its impact on society as a whole.

The second implication concerns a common misrepresentation of the fact that 'around $88 \%$ of soldiers who fought in the British Army during the First World War survived' (Pennell 2018, 88). Although Scotland's 'WW100' webpage mentions that Scotland and Scottish diasporas contributed over 700,000 soldiers to the British military and around 100,000 were killed in war, the experiences of those who survived war were neglected within the Centenary. The 
limited ability of the Centenary to facilitate discussions about veterans' unemployment, disabilities and other difficulties of post-war reintegration can be attributed to the emphasis on Scotland's military prowess discussed earlier in the paper as well as to the inherent insufficiency of British remembrance to engage with veterans beyond introducing them as 'a group who laid wreaths on Remembrance Sunday' (Gregory 1994, 194). Although Scotland's government has repeatedly expressed its commitment to support over 300,000 veterans residing in Scotland (Scottish Government 2017), within the Centenary veterans who served in the British Armed Forces during different conflicts, ranging from WWII to Iraq and Afghanistan, were mostly engaged as 'guardians' of the patriotic fallen.

Finally, as Ähall (2016) points out, the focus on the experiences of locally-born soldiers/families tend to (re)produce a specific - gendered polarised and heteronormative representation of war. The discursive and performative power of this gendered polarisation of war experiences lies in its ability to reframe these gendered divides as traditional and common sensical, thereby underscoring a key contribution of these gendered constructs in the effective functioning of the 'British warfare state' (Basham 2016). Our analysis suggests that this gendered discourse was aided by the ambivalent representations of Scottishness and Britishness in the Centenary which simultaneously introduced Scots as: "humble, simple beings' and 'all Jock Tamson's Bairns', as well as brave and loyal Highland warriors, who had served and died in Britain's wars. In other words, we argue that in the context of the Centenary, references to the 'Scottish egalitarian myth' (McCrone 2017, 239), did not only reinstate Scottish martial proweness, but enacted gender-stereotypical understandings of war. This gendered discourse has normalised a "celebration of soldiers, living and dead, as "heroes" who exemplify the values of the polity, making it much harder to question violence done and perpetrated by them' (Basham 2016, 892). Consequently, the implication of this masculine 'soldier-dead'-focused narrative was the (in)visibilisation of war experiences of many thousands of Scottish men and women who worked hard to feed their families during WWI, went on strike in the Glasgow docks and participated in anti-war protests (Couzin 2009). To further uncover the gendered logics of the Centenary, we explore the commemoration of Dr Inglis, whose name was added by the panel at a late stage in an attempt to 'celebrate the role of women in war through the lens of Elsie Inglis' (WW100 2018).

\section{The Creation of Dr Elsie Inglis as a Scottish War Heroine}


During our fieldwork, we were often faced with references to universalised and essentialised womanhood. This included us as women-researchers through such comments as 'you are women, you can come [to a Service of Thanksgiving for Inglis]' and 'there are enough women who are grateful that there is a moment when the role of women is specifically acknowledged'. We identify this as part of the modern liberal discourse of gender equality in Scotland, and explore this discourse through an investigation of the 'chronological similarity' in commemorations (Connerton 1989; see also Danilova 2015), which organisers attempted to enact through the (re)production of Inglis' 1917 funeral within the Service of Thanksgiving for Dr Elsie Inglis on 29 November 2017. This was a public event at which the following speakers were present: Dr Catherine Calderwood, Reverend Dr Lesley Orr, Hugh Pym, Patricia Purdom, Hugh Maddox and Reverend Helen Alexander. Our analysis is based on fieldnotes taken during and immediately after the Service. In particular, we problematise Inglis' associations with the British military; the (re)production of Scottishness, Britishness, class, race and the British Empire in relation to patriotic womanhood exemplified by Inglis; and the (mis)representation of feminism as a driving force for Inglis' war efforts.

\section{Patriotic Womanhood and the British Military}

Many scholars have pointed out that state-led nationalist projects tend to prioritise the figure of the soldier-warrior whilst ascribing to women symbolically reductive roles during wars (Elshtain 1995; Yuval-Davis 1997; Crozier-De Rosa and Mackie 2019). In our study, the ceremony for Inglis was held independently from other commemorative activities, (re)making Inglis into an embodiment of patriotic womanhood. This task was challenging as Inglis' offer of medical assistance to British soldiers was rejected by the War Office at the outset of WWI. This led to her work for Serbian, French and Russian soldiers who fought on the Eastern Front (Leneman 1991). To obscure this historical context, the 2017 service attempted to re-establish Inglis' belonging to the British military through specific performative and discursive means.

On a chilly November day, we hurried towards St Giles cathedral in Edinburgh, the entrance to which was restricted, and only after showing our personal invitations to the members of the Royal British Legion Scotland, we were allowed to enter and were directed towards our seats. The event was staged as women-orientated with women-soldiers, doctors, politicians and ourselves as researchers being invited to celebrate women's contribution to Scotland's wars. 
The ceremony was physically secured by veterans-members of the Royal British Legion Scotland, who acted as gate keepers and guardians of Inglis' memory. For the visitor entering the ceremony, there was a feeling of entering a military-controlled space, an environment which surrounded the entire story-telling of the event. The restriction of public attendance at the event further consigned the story of Inglis' life as one which should be told and heard mostly by individuals in elite positions. A small number of tickets were available for which the public could apply online; however, the seating plan and the spatial layout of the Cathedral was arranged such that the majority of audience members were unable to view the speakers, and only those in foremost positions - including Inglis' family members, politicians and royalty, represented by HRH The Princess Royal - were privy to the entire ceremony.

Inglis' symbolic belonging to the British military was further reinstated through the reproduction of her image (currently held at the London's IWM) dressed in what appears to be military uniform. Enloe (2003) in her work on everyday militarisation draws attention to the symbolism of khaki dress to militarise women's lives (see also Tynan 2016). In the context of Inglis' commemoration, the khaki constructed the idea of unproblematic integration of women within the British Armed Forces, while obscuring other gendered and historically sensitive readings of khaki dress. In Britain during WWI, women wore khaki for various reasons, one of which was to demonstrate defiance of traditional notions of masculinity and femininity. As such khaki was worn by feminists supportive of Britain's war efforts whose views Inglis shared (Kent 1988; Gullace 2002). Simultaneously, thousands of women wore uniform because of their service in the paramilitary units of the British Army with over 100,000 women serving (e.g. the Women's Army Auxiliary Corps, the Voluntary Aid Detachments, the First Aid Nursing Yeomanry), and over 700,000 women working in munitions factories across Britain (Roberts 1997; Lee 2006). In both cases the wearing of khaki by women of different occupations was perceived as 'profoundly disturbing', reflecting anxieties about women's expanding roles in war-time Britain (Summerfield 1997). These moral panics singled out working-class women as prone to 'loose sexual behaviour', 'irresponsible consumerism', and drunkenness, whereas women from middle- and upper-classes were often perceived as 'impersonating men' by challenging their dominance in the waging of war (Watson 1997, 37). Neither the 2017 service nor commemorative booklet engage with these complex gendered readings of khaki dress, and instead Inglis' image in the 'uniform' works towards providing a continuous narrative of women's service for the British military despite the fact that Inglis herself had never served in the British Army (WW100 Scotland 2017a). 
This staged performance of Inglis' militarised identity enacted the representation of British women-soldiers as both capable military professionals and 'ambivalent bodies' whose womanhood/motherhood is problematised by their military service (Basham 2013). The 2017 service for Inglis represented her as a patriotic and highly capable medical professional as well as a mother figure, in line with an essentialised feminine role. Inglis' 'motherhood' was signposted through her representation as 'the Serbian mother from Scotland', reinterpreting the fact that she spent most of her time treating Serbian soldiers (WW100 2017b); references to her 'caring and compassionate nature' (authors' field notes from the Service, 29 Nov 2017); and allusions to her commitment to provide 'care and comfort' to 'a whole generation of doomed young men' (Bellany in The Scottish Parliament 2016). These narratives introduced a hierarchy between Inglis' decades-long care for women from slums of Edinburgh before WWI and her work for the Scottish Women's Hospitals (SWH) treating soldiers during WWI. Through this hierarchy, the 2017 service re-established the traditional distinctions of masculine/feminine; public/private; and gendered divisions of labour whilst replicating the historical discourse of essentialised patriotic motherhood, popular during WWI (Grayzel 2011, 226-7).

Finally, similarly to the Centenary in England (Pennell 2018), the 2017 service in Edinburgh reinstated continuity in British military violence, representing it as forever present. Speakers at the event emphasised that remembering Inglis also means to pay tribute to all those who currently serve in the British Armed Forces and 'seek to make a difference for good', much 'like their ancestors' (authors' field notes from the Service, 29 Nov 2017). This discourse replicated the official designation of the British military operations in Iraq and Afghanistan in which a 'Force for Good' had attempted to 'make the difference' (Duncanson 2009), and through this re-alignment Inglis' service worked towards rewriting the causes of both WWI and modern conflicts as righteous and virtious, thereby obscuring their complex circumstances.

\section{Scottishness, Britishness, Class, Race and Empire}

The 2017 ceremony worked towards nationalising Elsie Inglis as a bearer of dual Scottish and British identities. St Giles cathedral was decorated with Scottish saltires, speakers put emphasis on the inspiring influence of Inglis' work for Scottish women and stressed that 'She made Scotland proud' (authors' field notes from the Service, 29 Nov 2017). Simultaneously, the performative context of the ceremony linked Inglis' Scottishness to the British state through 
the presence of royalty and the wearing of red poppies, both of which have conventionally been associated with British remembrance (Gregory 1994). These dual identity markers replicated the specific historical context in which Scotland positioned itself as part of the Union in the aftermath of WWI (MacLeod 2013). In the context of the 2017 service this convergence of Scottish and British identities reflected an elite-led drive towards the consensual commemoration identified earlier in this paper.

The 2017 service further attempted to nationalise Inglis' work by emphasising that she worked for 'the country' (Britain/Scotland) despite the historical fact that her efforts were rejected by the War Office thus: 'my good lady, go home and sit still' (WW100 2017a, 10). This response was not unusual at the time, and, 'because of sexism of the British authorities, British medical women wishing to serve in combat zones frequently enlisted with French, Belgian, Russian and Serbian Red Cross, for whom dire necessity outweighed any preference for male doctors'(Gullace 2002, 151). Although speakers during the 2017 ceremony acknowledged this context, the ceremony performatively worked towards erasing the uncomfortable fact that Inglis was not able to participate in her own nation's war effort.

The 2017 ceremony obscured differences in women's war experiences based on class and race, and through this obfuscation, it reinstated white middle-class femininity as the commemorative norm of the Centenary. This normativity resulted from disguising the specific historical context which gave rise to white, privileged Britishness. Leneman (1995) indicates: 'Elsie Inglis would have preferred "British Women's Hospitals" to "Scottish Women's Hospitals" but was overruled by the committee' $(1995,4)$. Presumably, Inglis's view reflected the fact that a significant proportion of women, who contributed their time, money and efforts to the SWH came predominantly from the privileged classes residing across the British Empire. Leneman (1995) mentions that Inglis was often perceived and described herself as English, British and Scottish, which reflected the fact that until Elsie was 12 years old she was in India, where her father was a senior member of the Indian Civil Service. Similarly, Grace McDougall, who was born in a privileged family in Aberdeenshire described herself as 'an Englishwoman' while serving as a nurse in Serbia (Lee 2006). Both McDougall's and Inglis' self-identifications reflected the context of Edwardian society in which women from privileged classes aligned their war-time patriotism with British imperialism according to which being 'English' meant 'to be white, Anglo-Saxon, a master-race, master indeed of a quarter of the world's people' (ibid, 87). 
Importantly, women from privileged backgrounds were able to train, self-finance and purchase their uniforms as part of their war-time service (Robert 1997). War-time work of thousands of working class women, who were employed in munitions factories, were recruited in the British nursing units, and who did similar work to women serving in the SWH were 'criticised... for not being sufficiently attuned to ideas of honour and service to the nation' (Watson 1997, 41) and appeared to care for their wages and new life styles. At the time, this stigmatisation of working class women's war work reflected the 'imperialist nationalism' according to which 'the British upper classes took responsibility and lead the crusade of restoring morality in the world (Lee 2006). Thus, the uncritical reproduction of this historically specific discourse within Inglis' 2017 service re-established class and, most importantly, white privilege as cornerstones of the Centenary, replicating the wider dominant ideology of white supremacy in Britain (Ware 1992). We argue that the 2017 service for Inglis worked towards the normalisation of 'whiteness' and class privilege, thereby obscuring the complex role of Scotland within the British Empire and marginalising war experiences of thousands of working class and non-white women.

Thus, although the 2017 service put particular emphasis on Inglis' example to inspire modern women residing in Scotland to pursue their careers, it expressed this idea through largely essentialised and universalised discourse. Accordingly, the structure of gender opportunities open (or closed) to women from under-privileged and multi-ethnic multiracial backgrounds currently studying and working in Scotland was obscured with emphasis placed instead on Elsie's legacy 'to show that, with determination, great things can be achieved by women as well as men' (WW100 2017a). This normalised the centrality of white middle class patriotic femininity to Scotland's wars.

\section{Patriotic Womanhood and Feminism}

The 2017 service for Inglis was also introduced to resonate with the approaching centenary of passing the Representation of People Act on 6 February 1918, which allowed women (over 30 years old and owning property) the right to vote for the first time in British history. In this context, Inglis' commemoration emerged as both an attempt to introduce her as a suffragist 'who campaigned tirelessly for women's rights' and through her career as a doctor and feminist speaker advanced the agenda of 'equality and diversity' in Scotland (WW100 2017a). However, the ceremony worked to subvert these emancipatory projects by reinstating 
conservative notions of patriotic womanhood. This was achieved through obscuring the feminist workings of the SWH and through a discourse which fluctuated between the paternalistic rhetoric of 'innocent victims' and the masculinising language of heroism.

During the 2017 service, speakers and the accompanying posters and leaflets praised Inglis' work for women's suffrage by putting emphasis on distinguishing her 'law-abiding' activism and campaigning through 'public talks' from 'the suffragettes who took direct action' and 'advocated militancy' (WW100 2017a, 8; authors' field notes from the Service, 29 Nov 2017). This representation of Inglis as a constitutional feminist aligns with elites' preference for the 'expert-bureaucratic' approach in pursuing the gender equality agenda discussed above (see also Johnson and Fife 2016). Moreover, the emphasis on Inglis' 'law-abiding' activism represents her as an individual heroine, who not only 'put on hold the campaign for women's rights' during WWI, but 'saw an opportunity to show the abilities of women to their fullest at the same time as doing her bit to aid the war effort' (WW100 2017a, 10). Drawing on feminist scholarship, we argue that this interpretation obscures the pivotal role of collective feminist efforts that created the SWH.

First, the distinction between 'peaceful'-constitutional and 'militant' feminisms misrepresents feminist activism during WWI. If prior to the war, suffragettes led by Emmeline and Christabel Pankhurst advocated the use of violence to promote women's rights, in August of 1914, all militant activities were 'suspended for the duration of the war, and instead they [suffragettes] adopted a fervently patriotic stance', using imperialist rhetoric and imagery in the main periodical renamed from The Suffragette to Britannia (Smith 2003, 103-4). Therefore, during the war, Pankhurst's patriotism coincided with the position of women like Inglis. This resulted in a high level of cooperation between different branches of the movement in support of the SWH (Leneman 1995). Furthermore, the 2017 service for Inglis and other commemorative materials omit the fact that in 1914, such prominent feminists as Sylvia Pankhurst and Virginia Woolf took an anti-war stance and drew attention to the negative impact of the war on the 'plight of working class women' (Smith 2003, 104). The complete omission of anti-war feminism from Inglis' commemoration (re)framed feminism as a war-supportive endeavour.

Second, the 2017 service put emphasis on the fact that Inglis' efforts were rejected by the War Office, an implication which suggests that this rejection occurred because all women could not serve on the frontline (WW100 2017a, 10). This interpretation not only misrepresents the 
reality that thousands of women served in the British units as nurses, ambulance drivers and in other non-combatant roles (Watson 1997; Robert 1997; Lee 2006). It also downplays Inglis' attempts to break down government-imposed barriers to women's war-time employment. For example, whereas women serving in the Voluntary Aid Detachments attached to British military hospitals 'were required to be single' and had to be between 21 and 48 years of age for Home Service, and 23 and 42 for Foreign Service (Watson 1997, 35). The SWH engaged women for all positions, including a significant proportion of married women and women of different ages - indeed, Inglis herself was 50 years old at the outset of the war (Leneman 1991; 1995). Although feminist work in support of the SWH did not overcome the barriers of class, race and ethnicity as it predominantly recruited white women from privileged classes, it mobilised all organisational resources, acting through feminist networks in support of the hospitals (Gullace 2002, 151). The reason for such feminist-driven mobilisation lay in the fact that hospitals themselves were considered a means to advance the campaign for women's franchisement. Thus, the dissociation of the SWH from the feminist movement in the 2017 service undermined understandings of feminism as political activism.

Contrary to the historical reality outlined above, during the 2017 service, the women involved in SWH are frequently referred to as 'girls', who wanted 'an opportunity to venture out on their own, "to do their own thing", not just want to marry this Sir or that Lord' (WW100 2017a, 15). In accompanying media reports, women are described as 'often unmarried and wanted to prove their independence and capability on the front line' (BBC 2017). This paternalistic representation of women's reasoning to join the hospitals replicated the early twentieth-century discourse according to which women, such as Inglis were not seen as a 'responsible adult but as someone who should have been protected rather than being allowed to risk all for her country' (Hughes 2005, 428). The dangerous work taken on by the women is often characterised through 2017 commemorative materials as being driven by 'a sense of adventure' (WW100 2017a, 15-16). This discursive strategy worked to minimise the personal risks undertaken by the women as well as to make light of their attempts to challenge their traditional positioning within British society at the time. Finally, Inglis' death is portrayed in terms of innocent and quiet suffering (WW100 2017a, 31). The implication of this framing is that Inglis had long suffered from cancer without the support of those around her. These narratives present reductive, paternalistic reasoning by removing from the story the radical and norm-challenging behaviour of the women and re-essentialising them as plucky young 'girls' who simply wanted to participate in a foreign 'adventure'. 
Alongside this patronising narrative, Inglis' commemoration positioned her as a masculine hero. In this contrasting discourse, Inglis is given the agency of a male soldier who perished at war and is characterised as having made the 'ultimate sacrifice' for her nation. Therefore, the historical discourse of war-time patriotism in Britain is reproduced, when women who served as nurses and doctors 'were deemed to be heroes worthy of commemoration' (Summerfield 1997, 6). The 2017 service, government-sponsored commemorative materials and accompanying media coverage replicated this masculinised essentialism by describing Inglis as 'brave and determined' (BBC 2017), which emphasized her courage in the face of dangerous conditions (WW100 2017a, 17). Finally, the replication of Inglis' funeral in 1917, which was conducted with full military honours and resembled that of a soldier killed in battle, reproduced the idea of military heroism.

The 2017 service for Elsie Inglis demonstrated the inability of the Centenary to move beyond the façade of pervasive cultural stereotypes of essentialised patriotic womanhood and masculinised heroism. This discourse undermined the feminist work of Inglis and her followers while introducing a patriotic war-supportive wing of British feminism as the most publically desirable political force. Moreover, it introduced the idea of unproblematic gender politics by obscuring the fact that only women over 30 years old who met property qualifications received the franchise in 1918 (see Crozier-De Rosa and Mackie 2019, 21). Furthermore, after WWI most women in Britain lost out in terms of employment opportunities through the post-war expectation that they return to their traditional roles of mothers, supporters of veterans, and keepers of home (Kent 1988, 238; see also Hughes and Meek 2014). In the 1920s, such gender stereotyping increased violence against women perpetrated by returning soldiers and caused a change in narrative in which suffragettes themselves encouraged women to return to their subordinate feminine roles in order to better protect their safety (Kent 1988, 249; see also Ward 2001, 25). Ironically, the Centenary reinstated the essentialisation of gender difference without facing the implications of such discourses for women who currently encounter gender-based violence in Scotland (McCrone 2017, 267; see also Engender 2014).

\section{The Gendered Legacy of the Scottish Commemorations}


As we walked from the cathedral out onto the Royal Mile, we noticed the placement of a Scottish military pipe band which, we presumed, was a continuation of the (re)production of Inglis' funeral procession of 1917. However, this purposeful re-creation of a funeral-like atmosphere in 2017 was hardly successful. Outside the cathedral, the sober and palpable atmosphere of Inglis' service evolved into a festive-like display of Scottish military culture. When crowds of tourists came rushing towards the band, we wondered if perhaps they had heard about Elsie Inglis. Driven by curiosity, we mingled and asked members of the public, 'what is going on?' The majority responded with a range of intriguing explanations. Some believed that the military band was present to play for HRH The Princess Royal, with American tourists particularly keen to catch a glimpse of the Princess. Others believed that 'something was going on' at the French Consulate across the square from the cathedral. Indeed, both Princess Anne and First Minister Nicola Sturgeon, who also attended Inglis' service, did go for a fleeting visit to the French Consulate either as an act of 'commemorative diplomacy' or simply for post-commemoration refreshments (e.g. Beamont 2015). Unfortunately, none of these explanations included Inglis, demonstrating the failure of this carefully organised commemorative spectacle to involve the broader public. This failure was reflective of the entire framing of the ceremony, which subverted the life work of Inglis and re-essentialised women as mothers, as mourners, as innocent victims and, paradoxically, as masculinised heroes; leaving the role of Scottish sacrificial soldier intact.

Despite predictions that Scotland's commemorations would be infused with nationalist sentiments following the 2014 Independence Referendum (Mycock 2014), our study has instead demonstrated the ambivalent nationalisms on display and has highlighted attempts to unproblematically link Scottishness and Britishness through an 'apolitical' commemoration which nonetheless drew on British nationalist and Scottish martial traditions alongside other cultural signifiers of British Empire and modern British militarism. In addition to these ambivalent nationalisms and militarisms, the Scottish Centenary has worked to reinforce gender, class and race through reinstating the dominance of Scottish martial identity represented by 'local soldier-lads', ancestors of Highlanders, and re-consigning women to traditionally feminine roles, thereby re-militarising their lives and subverting ideas and practices of feminist activism.

The paradoxes observed in this paper when it comes to attempts to deal with white privilege, elitism in commemorations, gender stereotyping, and the role of commemorations in infusing 
militaristic sentiments in Scottish society demonstrate that the Centenary provided limited spaces for debating and reframing such important issues. Instead, the discursive and performative framework of the Centenary transferred the ownership of memory to a closed, largely homogeneous, group of white male-dominated elites, inviting broader communities to engage through the keeping of respectful silence for the Scottish 'soldier-dead' and patriotic women. Ultimately, this framework prioritised passive forms of engagement with wars instead of critical reflective debate of how wars have been affecting Scottish society for the last centuries.

Regarding Inglis' service, as we have argued, such government devised and staged commemorations are unlikely to 'make them [personalities commemorated] live objects of concern and debate, tending instead to render them as more mute and inert' (Brown 2012, 250). From this perspective, the lack of opportunities for public deliberation over the focal points and implications of the Centenary subverts the principles of democratic politics by placing these projects outside of democratic accountability and debate over what, who and how should be commemorated. Instead, these practices foster gender-, race- and class-based stereotypes and therefore undermine efforts in building Scotland as an inclusive and fair political community. Importantly, the elite-led depoliticisation of the Centenary obscures the significant implications of how substantial commemorative budgets compare with ongoing cuts to Scottish local community budgets, educational, medical and welfare support services. Thus, based on our research, we see the most productive way to ensure the lasting legacy of the Centenary of WWI and such personalities as Elsie Inglis is by moving beyond commemoration based on gender essentialism of hero-soldiers and patriotic women, towards multifaced commemoration of efforts and losses of many thousands others whose lives were touched by British wars.

\section{Acknowledgements}

This paper results from the project, 'War Commemoration, Military Culture and Identity Politics in Scotland' funded by the Carnegie Trust for the Universities in Scotland, 2017-18 (RG13890/70560). The draft of this paper was presented at the EWIS in Groningen, 6-9 June 2018, and we would like to thank participants for instructive feedback. We also express our gratitude to those who promoted the legacy of Dr Elsie Inglis for many years, and agreed to comment on the draft of this paper. Finally, we would like to thank three anonymous reviewers for their constructive comments on earlier versions of this article as well as Cynthia Enloe and Andrew Mycock for their feedback and encouragement. 


\section{Bibliography}

Ähall, Linda. 2016. 'The dance of militarisation: a feminist security studies take on "the political"”, Critical Studies on Security, 4 (2): 155-168.

Allan, Stuart 2015. 'Beating retreat: the Scottish military tradition in decline', in B.S. Glass and J. M. MacKenzie (eds) Scotland, Empire and Decolonization in the Twentieth Century. Studies in Imperialism. Manchester: Manchester University Press, 131-54.

Arnold de-Simine, Silke. (2016) 'Between memory and silence, between family and nation: Remembering the First World War through digital media', in A. Dessingue and J. Winter (eds) Beyond Memory: Silence and Aesthetics of Remembrance. London: Routledge, 143161.

Basham, Victoria. 2013. War, Identity and the Liberal State: Everyday Experiences of the Geopolitical in the Armed Forces. London: Routledge.

Basham, Victoria. 2016. 'Gender, race, militarism and remembrance: the everyday geopolitics of the poppy', Gender, Place \& Culture: A Journal of Feminist Geography, 23 (6): 883-896.

BBC. 2013. 'Scots World War I commemorations announced by Alex Salmond', 23 May, https://www.bbc.co.uk/news/uk-scotland-scotland-politics-22642112 (accessed 10/08/2018).

BBC. 2014. 'Scotland commemorates World War One centenary', 4 August, https://www.bbc.co.uk/news/uk-scotland-28620000 (accessed 10/08/2018).

BBC. 2017. 'Elsie Inglis to be commemorated for war achievements', 8 November, http://www.bbc.co.uk/news/uk-scotland-edinburgh-east-fife-41915396 (accessed 10/08/2018).

Beaumont, Joan. 2015. 'Commemoration in Australia: a memory orgy?', Australian Journal of Political Science, 50 (3): 536-544. 
Brown, Steven D. 2012. 'Two minutes of silence: Social technologies of public commemoration', Theory \& Psychology, 22 (2), 234-252.

Brookfield, Karen. 2018. 'The People's Centenary: a perspective from the Heritage Lottery Fund', Cultural Trends, 27 (2): 119-124.

Butler, Judith. 2003. Precarious Life: The Powers of Mourning and Violence. London: Verso.

Butler, Judith. 2009. Frames of War: When is Life Grievable? London: Verso.

Cameron, Ewen. 2018. 'Securitization, Memory and the (Historic) Debate on Scottish Independence', in Vlad Strukov, Victor Apryshchenko (eds) Memory and Securitization in Contemporary Europe, 51-75.

Connerton, Paul. 1989. How Societies Remember. Cambridge: Cambridge University Press.

Couzin, John. 2009. Radical Glasgow: A Skeletal Sketch of Glasgow's Radical Tradition. $2^{\text {nd }}$ Edition, Glasgow: Voline Press.

Crozier-De Rosa, Sharon. and Mackie, Vera. 2019. Remembering Women's Activism. London: Routledge.

Danilova, Nataliya. 2015. The Politics of War Commemoration in the UK and Russia. Basingstoke: Palgrave Macmillan.

Devine, Tom. 2012. The Scottish Nation: A Modern History. London: Penquin Books.

Duncanson, Claire. 2009. 'Forces for Good? Narratives of military masculinity in peacekeeping operations', International Journal of Feminist Politics, 11 (1), 63-80.

Edkins, Jenny. 2003. Trauma and the Memory of Politics. New York: Cambridge University Press. 
Elcheroth, Guy and Reicher, Stephen. 2017. Identity, Violence and Power: Mobilizing Hatred, Demobilizing Dissent. Basingstoke: Palgrave Macmillan.

Elshtain, Jean. 1995. Women and War. Chicago: The University of Chicago Press.

Engender. 2014. 'Gender Equality and Scotland's Constitutional futures', https://www.engender.org.uk/content/publications/Gender-equality-and--Scotlandsconstitutional-futures.pdf (accessed 10/08/2018).

Enloe, Cynthia. 2003. Maneuvers: The International Politics of Militarizing Women's Lives. Berkley: The University of California Press.

Fathi, Romain. 2015. 'French commemoration: The centenary effect and the (re)discovery of 14-18', Australian Journal of Political Science, 50 (3): 545-552.

Grayzel, Susan. 2011. Women's Identities at War: Gender, Motherhood, and Politics in Britain and France during the First World War, Chapel Hill and London: The University of North Carolina Press.

Gregory, Adrian. 1994. The Silence of Memory. Armistice Day 1919-1946. Oxford /Providence: Berg.

Gullace, Nicola. 2002. "The Blood of Our Sons": Men, Women, and the renegotiation of British Citizenship during the Great War. New York: Palgrave Macmillan.

Hesse, David. 2014. Warrior Dreams: Playing Scotsmen in mainland Europe. Manchester: Manchester University Press.

Higgins, Michael and McKay, Fiona M. 2016. 'Gender and the development of a political persona: the case of Scottish First Minister Nicola Sturgeon', British Politics, 11 (3): 283-300.

Hughes, Anne-Marie, C. 2005. 'War, Gender and National Mourning: The Significance of the death and Commemoration of Edith Cavell in Britain', European Review of History, 12 (3) 425-444. 
Hughes, Anne-Marie, C. and Meek, Jeff. 2014. 'State Regulation, Family Breakdown, and Lone Motherhood: The Hidden Costs of World War I in Scotland', Journal of Family History, 39(4) 364-387.

Jeffery, Keith. 2015. 'Commemoration in the United Kingdom: A multitude of memories', Australian Journal of Political Science, 50 (3): 562-567.

Johnson, Karen. 2016. 'Politics of Gender Equality in Scotland: mind the gap', in T. McTavish, Duncan (ed) Politics in Scotland. London: Routledge. 160-179.

Kenny, Meryl. 2014. 'Engendering the independence debate', Scottish Affairs, 23 (3): 323-331.

Kent, Susan, K. 1988. 'The Politics of Sexual Difference: World War I and the Demise of British Feminism', Journal of British Studies, 27 (3): 232-253.

Lee, Janet. 2006. 'A Nurse and a Soldier: Gender, Class and National identity in the First World War Adventures of Grace McDougall and Flora Sandes', Women's History Review, 15(1):83-103.

Leneman, Leah, L. 1991. A Guid Cause: The Women's Suffrage Movement in Scotland. Aberdeen: Aberdeen University Press.

Leneman, Leah, L. 1995. In the Service of Life: The Story of Elsie Inglis and the Scottish Women's Hospitals. Edinburgh: Mercat Press.

Macleod, Jenny. 2013. 'Britishness and Commemoration: National Memorials to the First World War in Britain and Ireland', Journal of Contemporary History, 48 (4): 647-65.

McCrone, David. 2017. The New Sociology of Scotland. London: Sage.

Millar, Katharine. 2017. 'Gendered Representations of Soldier Deaths' in Rachel Woodward, Claire Duncanson (eds) The Palgrave International Handbook of Gender and the Military, 543-559. 
Moore, Christopher. 2014. '1914 in 2014: what we commemorate when we commemorate the First World War', The Canadian Historical Review, 95 (3): 427-432.

Mycock, Andrew. 2012. 'SNP, identity and citizenship: Re-imagining state and nation', National identities, 14 (1): 53-69.

Mycock, Andrew. 2014. 'The First World War Centenary in the UK: 'A Truly National Commemoration?', The Round Table: The Commonwealth Journal of International Affairs, 103 (2): 153-163.

Pennell, Catriona. 2014. 'A Truly Shared Commemoration?', The RUSI Journal, 159 (4): 92100.

Pennell, Catriona. 2016. 'Learning Lessons from War? Inclusions and Exclusions in Teaching First World War History in English Secondary Schools', History \& Memory, 28 (1): 36-70.

Pennell, Catriona. 2018. 'Taught to remember? British youth and First World War centenary battlefield tours,' Cultural Trends, 27 (2): 83-98.

Royal British Legion Scotland. 2018, https://www.legionscotland.org.uk/ (accessed 10/08/2018).

Ritchie, Nick. 2016. 'Nuclear Identities and Scottish independence', The Non-Proliferation Review, 23 (5):653-675.

Robert, Krisztina. 1997. 'Gender, Class, and Patriotism: Women's paramilitary units in First World War Britain', The International History Review, 19 (1):52-65.

Salmond, Alex. 2014. 'A good global citizen: Alex Salmond's speech on Scotland's role in the world', The Open Democracy, 9 April, https://www.opendemocracy.net/ourkingdom/alex-salmond/good-global-citizen-alexsalmonds-speech-on-scotlands-role-in-world (accessed 10/08/2018). 
The Scottish Government. 2013. 'Scottish Commemorations Panel: objectives', 1 August, https://beta.gov.scot/publications/scottish-commemorations-panel-objectives (accessed 10/08/2018).

The Scottish Government. 2017. 'The Veterans Community - Employability, Skills and Learning: Scottish Government Response', March.

https://www.gov.scot/Publications/2017/03/6836 (accessed 10/08/2018).

The Scottish Parliament. 2013. 'Meetings of the Parliament', 27 June. Session 4, no. 21763, 'First World War (Centenary)'.

http://www.parliament.scot/parliamentarybusiness/report.aspx? $r=8740 \&$ mode $=p d f($ accessed 10/08/2018).

The Scottish Parliament. 2016. 'John Bellany: Bringing History to Life at the Scottish Parliament':

http://www.parliament.scot/newsandmediacentre/95672.aspx (accessed 13/08/2018)

Sheffield, Gary. 2014. 'A Once in a Century Opportunity? Some Personal Reflections on the Centenary of the First World War', British Journal for Military History, 1 (1): 1-11.

Smith, Angela K. 2003. 'The Pankhursts and the war: suffrage magazines and First World War propaganda', Women's History Review, 12 (1): 103-118.

Streets, Heather. 2004. Martial races: The military, race and masculinity in British imperial culture, 1857-1914. Manchester: Manchester University Press.

Sturken, Marita. 2007. Tourists of History: Memory, Kitsch, and Consumerism from Oklahoma City to Ground Zero. New York: Duke University Press.

Summerfield, Penny. 1997. 'Gender and War in the Twentieth Century', The International History Review, 19 (1): 3-15. 
Tynan, Jane. 2016. 'Researching the Visual and Material Cultures of War and Conflict' in Alison J. Williams, Neil Jenkings, Rachel. Woodward and Matthew F. Rech (eds) The Routledge Companion to Military Research Methods. Abington: Routledge, 301-316.

Ward, Paul. 2001. “Women of Britain Say Go": Women's Patriotism in the First World War', Twentieth Century British History, 12 (1):23-45.

Ware, Vron. 1992. 'Moments of Danger: Race, Gender and Memories of Empire', History and Theory, 31 (4): 116-137.

Watson, Janet S. K. 1997. 'Khaki Girls, VADs, and Tommy's Sisters: Gender and Class in First World War Britain', The International History Review, 19 (1):32-51.

Wellings, Ben. 2016. 'First World War commemorations in Belgium and the Netherlands: comparative perspectives', BMGN-Low Countries Historical Review, 131 (3): 99-109.

WW100 Scotland. 2017a. Elsie Inglis and the Scottish Women's Hospitals. A booklet. Edinburgh: Scottish Government.

WW100 Scotland. 2017b. 'Dr. Inglis: A Serbian mother from Scotland', http://ww100scotland.com/blog/dr-elsie-inglis-the-serbian-mother-from-scotland/ (accessed 10/08/2018).

WW100 Scotland. 2018. http://ww100scotland.com/panel/ (accessed 10/08/2018).

Yuval-Davis, Nira. 1997. Gender and Nation. London: Sage.

\footnotetext{
${ }^{1}$ The project received support from the Committee for Research Ethics and Governance at the School of Social Science, the University of Aberdeen. The research team utilised a mixed method qualitative methodology, including critical discourse analysis of government-produced commemorative publications, parliamentary debates, stenogrammes of meetings and other relevant documents. We also deployed participant ethnographies of commemorative events as a key way to gauge the information about how events are performed. As part of the whole project, we conducted 27 interviews with policy makers, curators of military museums, representatives of the Royal British Legion Scotland and Poppy Scotland, Education advisers, and members of other war-themed organisations. In this paper, we predominantly rely on the analysis of documents and participant ethnographies, utilising interviews only as a means to triangulate our interpretations. Each interviewee has been anonymised and given a code letter.
} 